\title{
Philippe Halsman'ın "Jumpology" Adını Verdiği Portre Fotoğrafları ve Yüzü Farklı Görme Biçimi
}

Doç. Dr. Şebnem SOYGÜDER BATURLAR

Ege Üniversitesi, İletişim Fakültesi

Radyo, Televizyon ve Sinema Bölümü

sebnem.soyguder@ege.edu.tr

ORCID: 0000-0002-9618-171X

\begin{abstract}
Öz
Philippe Halsman, dünyanın önemlive ilginç portre fotoğrafçılarındandır. Günümüzde çoğumuzun belleğinde yer eden ikonik kabul edebileceğimiz, ünlülere ait birçok portre fotoğrafı Halsman'a aittir. 1940'lardan 50'lere kadar Amerika'daki ünlülerin (artistler, sanatçılar, siyasetçiler, devlet adamları vb.) portrelerini çektikten sonra (ki bunlar başta LIFE olmak üzere pek çok önemli dergi kapağında yer almıştır) 1950'lerin başında model olarak ele aldığı bu kişileri "zıplatarak" fotoğraflamış ve yeni bir görme biçimi ortaya çıkarmışıır. Bu çekim tekniğine de "jumpology" yani zıplama bilimi ismini vermiştir. Makalede ünlüleri zıplatma sebebi ve "yüz" hakkındaki görüşlerinden bahsedilecektir. Çalışmamızda özellikle Salvador Daliile birlikte tasarlayıp hiçbir photoshop gibi fotoğraf düzenleme uygulaması kullanmadan çektiği ve objelerin havada asılı kaldığı anı görüntülemeye çalıştığı illk fotoğrafı olan Dali Atomicus isimli eser anlatılacaktır. Çünkü bu eser, uzun süre kullanacağı ve dünya fotoğraf mirasının önemli bir parçası olan havada asılı kalma, zıplatma (jumpology) tekniği Halsman'ın farklı görme biçiminin başlangıcı olmuştur. Çalışma tarihsel nitel bir araşııma yöntemidir ve amaca yönelik seçilen örnek fotoğraflar Halsman'a ait olan eserlerden bazılarıdır.
\end{abstract}

Anahtar Kelimeler: philippe halsman, zıplama bilimi, portre, yüz, dali atomicus

Soygüder, Ş. (2021). Philippe Halsman'ın "Jumpology" Adını Verdiği Portre Fotoğrafları ve Yüzü Farklı Görme Biçimi. ARTS: Artuklu Sanat ve Beşeri Bilimler Dergisi, 6, 305-328. 


\title{
Philippe Halsman's Portrait Photographs Named "Jumpology" and His Different Way of Seeing the Face
}

\begin{abstract}
Philippe Halsman is among world's prominent and interesting portrait photographers. Many iconic portrait photographs of celebrities resting in our memory today are Halsman's. From 1940's till 1950's, he took portrait photographs of American celebrities (artists, politicians, etc.) which appeared on the covers of significant magazines such as Life. In early 50's, he put forth a new way of seeing by photographing his famous models as they "jumped". He named this type of photography as "jumpology". This study puts forward the reason why he made the celebrities jump along with his opinions concerning "face". The study particularly examines Dali Atomicus which was designed together with Salvador Dali without using any editing programmes such as Photoshop and in which Halsman tried to photograph the moment the objects hung in the air. It was noted as the beginning of Halsman's different way of seeing called jumpology which he used for long years, and which has become an important part of world photography heritage. Through a historical qualitative analysis, the study analyses some of Halsman's photographs which have been goal-oriented selected.
\end{abstract}

Keywords: philippe halsman, jumpology, portrait, face, dali atomicus 


\section{arts $=$}

\section{GíRiş}

Philippe Halsman, fotoğrafa çocuk yaşlarda portre çekerek başlamış hayatının sonuna dek de portre fotoğrafları çekmiştir. İkinci Dünya Savaşı sırasında Paris'ten New York' a göç eden sanatçı 1940' larda Amerika' da ünlüleri fotoğraflamış ve kısa zamanda kendisi de ünlü bir portre fotoğraf sanatçısı olarak tanınmıştır.

Bedenin sahnesi olarak kabul edilen "yüz", onu yansıtan "portre" yazılı ve sözlü edebiyattaki betimlemelerden resim, heykel, fotoğraf, grafik, tiyatro ve sinema gibi görsel sanat dallarına kadar neredeyse tüm sanat dalında kendini göstermiştir. Çalışma fotoğraf sanatındaki portrenin farklı görme biçimi üzerinedir.

Ünlülere ait kolektif görsel bellekte yer eden ikonik değerdeki pek çok portre fotoğrafı Halsman'a aittir. Kariyeri boyunca sinema, televizyon ve tiyatro yıldızlarını, şarkıcıları, ressamları, futbolcuları, siyasetçileri, devlet adamlarını, bilim insanlarını fotoğraflamıştır. 101 kez Life Dergisi kapağında Halsman'ın çektiği portreler kullanılmıştır. Bunun dışında TIME, Look, Paris Match ve Stern gibi dergilerde de sanatçının sayısız portre fotoğrafları yer almıştır.

Halsman, çalışma konumuzla ilgili olarak iki önemli kitap yayınlamıştır. Çalışmamızda bu kitaplardan söz edilecektir. Ilki fotoğrafçılara yaratıcı fotoğraflar çekmenin yöntemini anlattığı Halsman on the Creation of Photographic Ideas, ikinci kitabı ise 1952 'lerde başladığı ve altı yıl süren ünlüleri zıplatarak çektiği içinde portre fotoğraflarının ve katıımcıları (ünlüleri) neden zıplattığına dair ortaya attığı hipotezinin yer aldığı Philippe Halsman's Jump Book isimli kitabıdır.

Çalışma, özellikle ikinci kitabında yazdığı ve "jumpology" adını verdiği zıplama biliminin portre sanatına kattığı yeni görme biçimi ile ilgilidir. Ancak bu terimi kullanmaya geçmeden yine oldukça ikonografik olan Dali Atomicus adlı eserine de önemli ölçüde değinilmiştir. Çünkü zıplama ve havada asılı kalma olgusu 1948'deki sürreailst kabul edilen bu ilginç eserle başlamıştır.

Halsman 1941 yılında dünyanın en ünlü sürrealist ressamlarından Salvador Dali ile tanışır ve arkadaş olur. Halsman'ın gerçeküstücülüğe olan sempatisi, Salvador Dali ile uzun (37 yıl) ve verimli dostluğuna dayanmaktadır. Uzun yıllar birlikte çalışılar. Dali İkinci Dünya Savaşı sonrası atom konusuna ilgi duyar. Atom çekirdeğinin etrafında havada dönen elektron ve protonlar ve bunların birbirine değmiyor olması Dali'yi çok etkiler. Bu merak ve ilgi yaptığı resimlerine de yansır. Halsman da atom çağına giren dünyamızda Dali'nin de etkisiyle şeylerin havada asılı kalması konusuna ilgi 
duyar. Bu konuyu çalışmalarında kavramsallaşıııı.

Yerçekimi kuralını devre dışı bırakarak, ünlüleri zıplatarak çekilen portre fotoğraflarında kişilerin gerçek kişiliklerini yansıttıklarına vurgu yapmaktadır. Tıpkı parmak izi gibi aslında herkesin farklı zıpladığını ve zıplama anında poz verilmediğini, o coşku ve heyecanla ne isek o şekilde görüldügümüzün altını çizer. Bunu da fotoğrafın psikolojik bir aracı olarak niteler.

"Insan yüzüne duyulan bu hayranlık beni asla terk etmedi... Gördüğüm her yüz saklanıyor ve bazen başka bir insanın gizemini açığa çıkarıyor... Bu ifşayı yakalamak hayatımın hedefi ve tutkusu haline geldi..." (Panzer, ___).

Çalışmamız tarihsel bir niteliksel araştırmadır. Halsman'ın belirttiği teorinin (jumpology) doğruluğu ya da yanlışlığı tartışılmayacaktır. Ortada duran bir gerçek varsa o da bu fotoğraflama tekniği ile üretilen fotoğrafların dünya fotoğraf külliyatı içinde önemli bir yeri olmasıdır. Katıımcıları neden zıplattığını anlamaya çalışmaya yönelik bir çalışmadır.

\title{
Philippe Halsman Kimdir?
}

Halsman'ın web sitesinde kendisi hakkında yazdığı otobiyografisinden kısa bir özetle bilgi vermek gerekirse; 1906 Letonya doğumludur. 15 yaşında çatı katında bulduğu bir fotoğraf makinesi ile fotoğraf çekmeye merak sarar. İlk çektiği konu kIz kardeşinin portresidir. Evinin banyosuna harçlıklarıyla kurduğu karanlık odada fotoğraflarını karta basar. Şöyle demektedir:

\begin{abstract}
Çoğunlukla arkadaşlarımı, kız arkadaşlarımı ve arkadaşlarımın kız arkadaşlarını fotoğrafladım. Tasvir etmeye çalışıı̆ıım yüzlerdi. Her zaman insan yüzüne hayranlik duymus hep portre çekmeyi istemiştir. Gördüğüm her yüz, başka bir insanın gizemini gizliyor ve bazen de geçici olarak açığa vuruyor gibi görünüyor. Daha sonra, bu vahyi yakalamak hayatımın hedefi ve tutkusu oldu. Kamerama bakan insanların en içteki benliklerinin yansımalarının koleksiyoncusu oldum (Philippe Halsman Archive, 2015).
\end{abstract}

On sekiz yaşında Almanya'nın Dresten şehrinde mühendislik okumaya gider. Fakat mezun olmasına birkaç ay kala fakülteyi terk edip moda fotoğrafları çekme hayali ile Paris'e yerleşir. Aklı fikri portre fotoğraflarındadır. Bir fotoflood lamba ve büyüteçle aylarca denemeler yapar. Aydınlatma ile insan yüzünün çeşitli duygularını yakalayabileceğini keşfeder. "Aydınlatmanın sadece aydınlatma olmadığını, aynı zamanda güçlü bir karakterizasyon aracı olabileceğini çok net bir şekilde fark ettim" der. "Fotoğraf bana halâ keşfedilmemiş görünüyordu, büyümekte gelişmekte olan bir sanat". Halsman'ın mühendislik alt yapısı fotoğrafta çok işine yaramıştır. 


\section{arts}

Makinelerini mühendislik birikimi ile kendi tasarlar.

1930'larda Paris'in sanat merkezi olan Montparnasse'nin merkezinde bir fotoğraf stüdyosu açar. Çekip karta bastığı fotoğrafları insanların görmesi için açtığı stüdyonun duvarına cam bir vitrin yerleştirip sergiler. "Her hafta vitrine 4-5 fotoğraf koyup bunları sürekli değiştirdim. Kısa süre sonra insanlar en son çalışmamı görmek ve tartışmak için vitrinimin altına gelmeye başladılar" (Philippe Halsman Archive, 2015). Portrelerin bir vitrinde sergilenmesi fikri de Halsman'a aittir.

Halsman mühendislik bilgisi ile kamerasına yenilikler eklemiştir. Daguerre için ilk kamerayı yapan marangozun torunu olan eski bir marangozu bulur. Düşündüğü tasarımı ince bir işçilikle ve en iyi maun ağacını kullanarak bu marangoza yaptırtır. Daguerre ile 210 mm Tessar lensini eşleştirir. Kimsenin sahip olmadığı bu yeni alet, çektiği portre fotoğraflarının tarzını etkiler.

"Bir nesneye (modele) bakan, bir izleyici olan kameranın yanında durmak yerine, şimdi artık kameradan modele bakıyordum. Model gözümle buluşmak için merceğe bakmak zorunda kaldı. Sonuç olarak, bir cam merceğe bakan insanların anlamsız ifadelerini değil, bir kişiliğin tüm etkisini gösteren ifadeleri yakalayan fotoğraflar çekmeye başladım (Philippe Halsman Archive, 2015).

Daha çok tanınır, aktörler ve yazarlar fotoğraf çektirmek için kendisini ararlar. Voila, Vu ve Vogue gibi moda dergilerinde çalışır. Bir makalede kendisi ile ilgili olarak "Muhtemelen Fransa' nın en iyi portre sanatçısı" diye yazıldığını okur. O günden sonra üzerinde büyük bir sorumluluk hisseder ve daha çok çalışır.

Paris, İkinci Dünya Savaşı sırasında düştüğünde önce eşini ve kızını Amerika'ya gönderir. Daha sonra Amerika'daki Profesör Einstein'ın yardımı ile kendisi de Amerika Birleşik Devletleri'ne kaçar. 10 Kasım 1940'ta Amerika'ya gelir. Zor şartlar altında ailesi ile yaşamaya başlar. Fransa'da tanınan Halsman'ı Amerika'da hiç kimse tanımamaktadır. Beş dil bilmesine rağmen Ingilizce bilmemektedir. Fotoğrafçılık kariyerini en baştan, aşağıdan yukarıya tekrar inşa etmek zorunda kalmıştır. Fotoğraf ajansı Black Star'da çalışır. Geçimini sağlayabilmek için sirk ve birçok geçit töreni de dahil olmak üzere çok çeşitli konularda fotoğraf çeker.

Halsman'ın Amerika Birleşik Devletleri'nde tanınıllı̆ı kozmetik ürünleri devi olan Elizabeth Arden'in bir ürünü (ruj) için bastığı reklam afişi ile başlar (Görsel 1).

Bir gün bir model ajansında genç bir kızın profilinden etkilendim. Benim için Amerika'da sevdiğim her şeyi sembolize etti: Gençlik, güzellik ve bu yeni ülkenin gücü. Kızın adı Connie Ford'du; on sekiz yaşındaydı. "Amerikan Profili" diyebileceğim bir fotoğraf yapmaya karar verdim. Kâğıttan bir Amerikan bayrağı aldım. Aydınlatmam iki sıradan projektörden oluşuyordu. Connie'yi duvarı bayrakla kaplanmış odaya aldım ve bayrağın üzerine başını koydurdum. Connie fotoğrafı beğendi ve portföyüne koydu (Philippe Halsman Archive, 2015). 


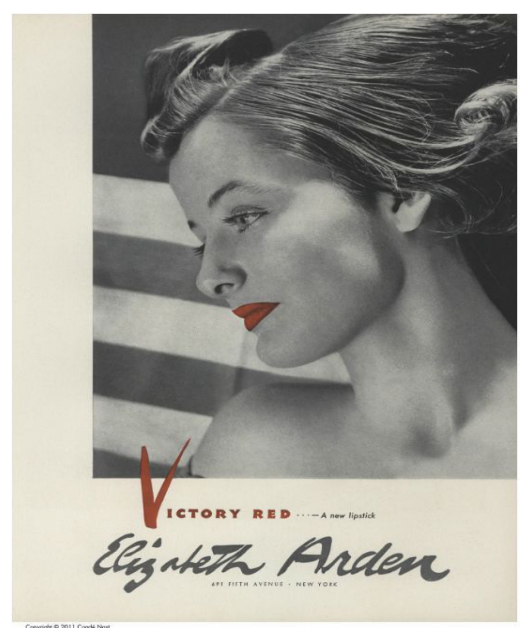

Görsel 1. Philippe Halsman, Connie Ford, 1941.

Elizabeth Arden'in "Victory Red" ruj kampanyası için bu fotoğrafı kullanır. Fotoğraf yayınlandıktan sonra "Sanat Yönetmenleri Kulübü Madalyası"nı kazanır ve Halsman'ın Amerika'daki kariyeri başlar. Her biri ikonik değer taşıyan yüz bir (101) adet portre fotoğrafı LIFE Dergisi'ne kapak olur. Halsman'ın fotoğrafını çektiği ünlüler arasında Alfred Hitchcock, Judy Garland, Winston Churchill, Marilyn Monroe, Dorothy Dandridge, Albert Einstein, Lovis Armstrong, Elizabeth Taylor, Barbra Streisand, Brigitte Bardot, Salvador Dali ve Pablo Picasso ve daha pek çok ünlü isim yer almaktadır. Bazılarını örnek olarak göstermek gerekirse (Görsel 2-5);

Barthes'a göre portre fotoğrafı kapalı bir kuvvetler alanıdır. Burada dört görüntü repartuvarının kesiştiğinden, birbirine karşı koyduğundan bahseder. "Bunlar: Mercek önündeki ben, aynı anda: Olduğumu sandığım, başkalarının olduğumu sanmalarını istediğım, fotoğrafçının olduğumu sandığı ve fotoğrafçının sanatını göstermek için kullandığıyımdır" der ve portre fotoğrafı çektirdiğinde adeta ölümün mikro düzeyde bir çeşidini yaşadığını söyler (Barthes, 2000, s. 27-28).

Halsman, bütün çektiği o yıldız fotoğraflarının içinden en çok Einstein'ın fotoğrafından etkilendiğini söyler. Halsman' a değil sanki dünyanın gidişatına bakıp, beklenmedik bir anda, çekim anında ışı̆̆ını söndürüp hüzne dalmış bir Einstein (Tulgar, 2017, s. 38).

1947 yılında fotoğrafladığı Albert Einstein'ın hüzünlü yüzü sonradan 1966 yılında Amerikan posta pulu üzerinde, 31 Aralık 1999 yılında ise TIME Dergisi kapağında "Yüzyılın Kişisi" manşeti ile kullanılmıştır (Golden, 1999). 

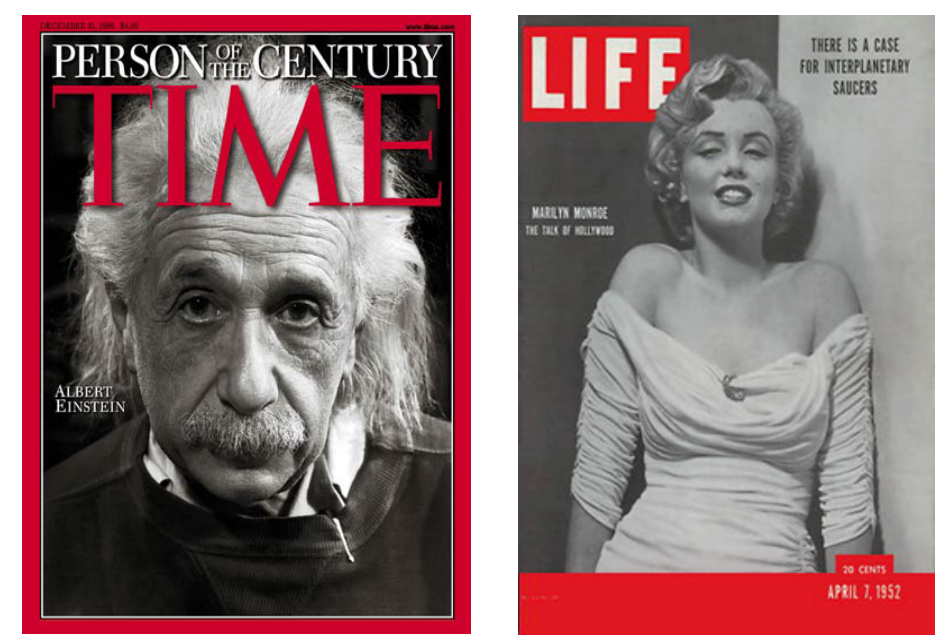

Görsel 2. Philippe Halsman, Albert Einstein, 1947.

Görsel 3. Philippe Halsman, Marilyn Monroe, 1952.
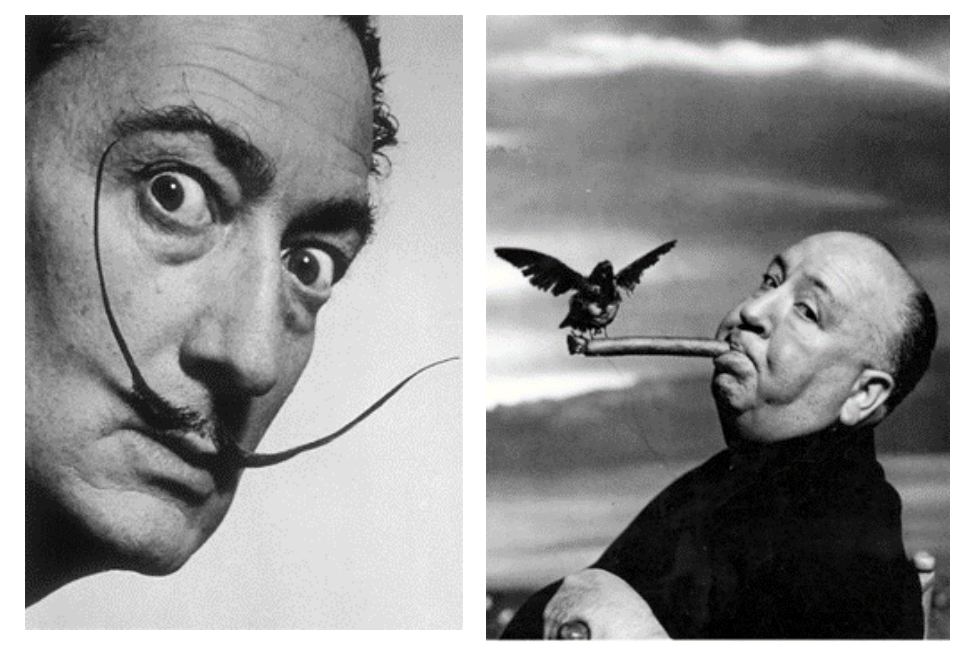

Görsel 4. Philippe Halsman, Salvador Dali, 1954.

Görsel 5. Philippe Halsman, Alfred Hitchcock, 1962.

Basın ve basın fotoğrafçılığı tarihinde LIFE Dergisi çok önemlidir. LIFE ve ona rakip dergilerden önce Amerikalılar dünyayı gazetelerden, radyodan ve haber programlarından öğreniyorlardı. Ancak bu yeni çıkan fotoğraflı dergiler dramatik ve çarpıcı fotoğraflarla dolu sayfalar yayınlayarak Amerikalılara başka hiçbir medyanın ulaşamayacağı taze bilgileri ulaştırmıştır. Life çok başarıı, tirajı yüksek bir dergi olmuştur.

1940'ların başında Salvador Dali ile tanışır. Aralarında sonradan birlikte olağandışı fotoğraflar üretecekleri bir dostluk kurulur. Hatta üretilen "Dali Atomicus" ve "Jumpology" fotoğrafları Halsman'ı sürrealist fotoğrafçılar sınıfına dahil edecektir. 


\section{Jumpology Öncesi Sürreailst Bir Deneme: Dali Atomicus}

Halsman 1948 yılına kadarünlülerin portre çekimleriyle tanınan ve bu başarısıyla kendisinin de ün kazandığı bir fotoğrafçıdır. İkonik olarak değerlendirebileceğimiz evrensel bellekte yer eden ünlülere ait birçok fotoğrafa imza atmıştır.

Ünlüleri zıplatarak farklı görme biçimi yarattığı, "Jumpology" adını verdiği ve çalışmamızın da ana konusu olan bu çekim tekniğine aynı zamanda arkadaşı olan ünlü sürrealist ressam Salvador Dali ile birlikte ortaya çıkardıkları Dali Atomicus adlı eser kaynaklık etmiştir.

Halsman, "Dali Atomicus"u Salvador Dali'nin henüz tamamlamadığı Leda Atomica adlı yağlı boya eserinden ve ayrıca elektronik flaşın mucidi elektrik mühendisi ve fotoğrafçı olan Dr. Harold E. Edgerton'un 1936 yllında çekmiş olduğu Süt Damlası (Milk Drop) adlı fotoğrafından ilham almıştır. Bunları Halsman, 1961 ylında yayımlanan Halsman on the Creation of Photographic Ideas adlı kitabında tüm detaylarıyla anlatmaktadır. Kitabın üç baskısı olmuştur. Bu çalışmada aynı eserin 1963'de yayınlanan üçüncü baskısı kullanılmıştır.

Kitabında yazdığına göre bir gün Dali'ye neden eserinin isminin Leda Atomica olduğunu sorar. Dali de şöyle açıklar: "Atomun bir çekirdekten, protonlardan, nötronlardan, elektronlardan oluştuğunu öğrendim. Hepsi çekirdeğin etrafında havada (asılı) dönüyor. Zamanımızın modern ressamı olarak ben de her şeyi havada asılı halde boyamalıyım" (Halsman, 1963, s. 54). Halsman'a esin kaynağı olan, ancak Dali'nin o sıra henüz tamamlamadığı, tabloda yer alan her şeyin birbirine değmeden havada uçuştuğu Leda Atomica adlı eserini konumuz çerçevesinde kısaca açıklamak gerekirse (Görsel 6):

Bu tabloda Dali'ye Yunan mitolojisinden Leda efsanesi ilham kaynağı olmuştur. Zeus düğün gecesinde Leda'yla birlikte olabilmek için bir kuğuya dönüşür (Bilindiği gibi Yunan mitolojisinde Zeus birlikte olmak istediği kadınlara farklı şekil ve formlarda yaklaşmaktadır. Bulut olur, yağmur olur, boğa olur, kuğu olur vs.). Bu ilginç mitolojik hikâye sanat tarihi boyunca birçok ünlü ressamın ilgisini çekmiş ve çok kereler resmedilmiştir.

Eserin ana figürü olan Leda, Dali'nin eşi Gala'dır (Dali'nin birçok eserinde olduğu gibi). O sıralar atom teorisinden etkilenen Dali resimdeki hiçbir nesneyi birbiri ile temas ettirmemiştir. Bir kaidenin üzerinde oturan eşi Gala (Leda) kanatlarını açarak ona yaklaşan kuğunun boynunu kavramak üzeredir. Eserin geri planında 
görülen manzara Dali'nin eserlerinde sıkça görülen Katalonya'nın Costa Brava sahilindeki Cap Norfeu kayalıklarıdır. Eserdeki hiçbir nesnenin birbirine değmediği görülecektir. Kaidenin tüm parçaları adeta havada uçuşmaktadır. Eserdeki diğer öğeleri yani yumurta kabuğu, damlalar, kitapçık ve gönye de aynı şekilde havalanmıs ve birbirine veya herhangi bir yüzeye temas etmemektedir. Gala oturur gibi görünse de aslında kaidenin üstüne tam oturmamakta, ayakları da basamaklara değmemektedir. Yanına yaklaşan kuğuya dokunur gibi yapsa da aslında ona da dokunmamaktadır. En ilginci de denizin suyu kumsalın üzerine bir hizada, ayrı bir katmanmış gibi durmaktadır. Dolayısıyla tüm nesneler havada asııı kalmış moleküller gibi görünmektedir. Eserde yer alan kuğu dışındaki tüm nesnelerin gölgesi vardır. Çünkü kuğu, tanrıların tanrısı Zeus'un vücutlaşmış halidir. Bu dünyadan değildir. Dolayısıyla da bir gölgesi yoktur (Sanata Başla, 2014).

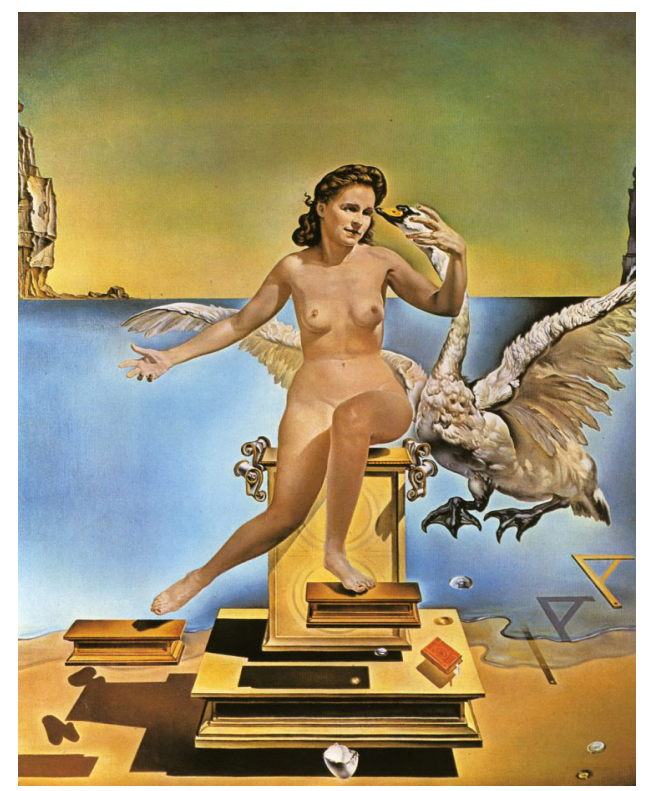

Görsel 6. Salvador Dali, Leda Atomica, 1949.

Dali bu eseri hakkında şöyle bir açıklamada bulunur: "Leda Atomica, bizim yaşamımızı (eşi ve kendisini kastediyor) açımlayan resimdir. İçinde ne varsa boşlukta asılıdır, hiçbir şey hiçbir şeye değmez. Deniz bile yer yüzünden biraz uzakta asılı durur" (Neret, 1997, s. 69).

Halsman'ın Dali Atomicus adlı eserine ilham veren bir diğer çalışma ise yukarıda da söz edildiği gibi Dr. Harold E. Edgerton'un 1936 yılında çekmiş olduğu Süt Damlası (Milk Drop) adlı fotoğraftır (Görsel 7). Yazdığı kitabında bu konuyla ilgili olarak Dali'nin kendisine “Harold E. Edgerton'un çektiği süt damlasının fotoğrafını gördün mü? Süt damlası sıçradığında nasıl taç gibi şekil alıyor" dediğinden söz eder 
(Halsman, 1963, s. 54).

Aynı zamanda elektronik flaş stroboskobun da mucidi olan Harold Edgerton, 1936'da süt damlasının yüksek hızı fotoğrafını çeker. Süł damlası ince bir sıvı katmanına çarpar, yayılır ve yüzey gerilimi nedeniyle parçalanan bir taç şeklini oluşturur (Versluis, 2013).

Edgerton, bir tabağa düşen süt damlası dışında bir topa vuran tenis raketini, elmayı veya oyun kartını delip geçen mermilerin hareketini, kısaca "hızı" fotoğraflamıştır. Ortaya çıkan bu görüntülerin kuşkusuz endüstri ve bilime katkısı çok büyüktür ancak aynı zamanda bunlar sanatsal değere sahip çok güzel eserlerdir. Bilime olduğu kadar fotoğraf sanatına da yön veren eserlerdir.

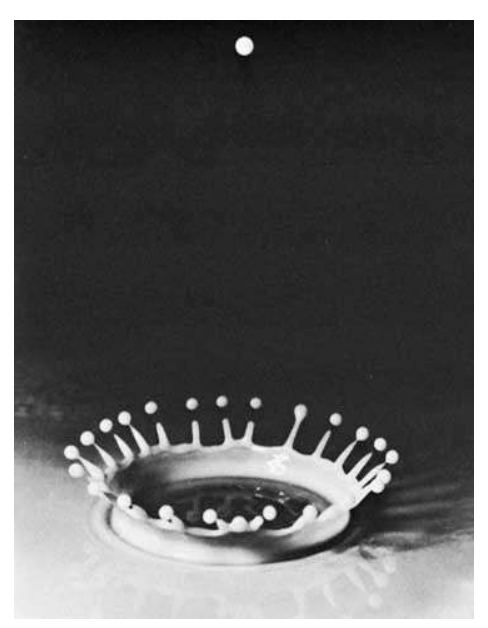

Görsel 7. Harold E. Edgerton, Milk Drop, 1936.

Salvador Dali, Halsman'a bir kova süt ve bir kediyle bunu denemelerini önerir. Fakat Halsman "Su alalım, çünkü süt şeffaf olmadığı için kedinin süte batmış yarısını görmeyeceğiz". Ayrıca Avrupa'da İkinci Dünya Savaşı henüz bitmiştir, küçük çocuklar açlıktan ölüyorken bu fotoğraf denemesinde süt kullanmanın doğru olmayacağını söyler ve ikili çalışmayı bir kova su ile yapmaya karar verir (Halsman, 1963, s. 55).

Halsman, arkadaşı Dali'ye "Dali Atamicus" isimli fotoğraf projesi için harika bir fikri olduğunu söyler. "Fotoğraftaki her şey havada (asılı) olacak sen, şövale ve resmettiğin konu (Leda Atomica)... kısaca her şey - asılı!" (Halsman, 1963, s. 54).

Halsman çekimi New York' taki stüdyosunda, bir sene önce kendi hazırladığı 4 x 5 formatındaki çift lensli fotoğraf makinesini kullanarak yapar (Altun, 2015).

Bu sahneyi oluşturmak için neredeyse görünmez ince bir tel kullanarak Dali'nin şövalesini, bir tabureyi ve Leda Atomica adlı tablosunun bir baskısını asarak bunları havada asılı tutar. Halsman'ın eşi, yerçekimi eksikliği yanılsamasına katkıda 
bulunmak için çerçevenin hemen solunda bir sandalye tutar. Üç asistanı üç kediyi, dördüncü asistanı ise bir kova suyu havaya firlatmak üzere komut bekler. Halsman dörde kadar sayar. "Üç" dediğinde asistanlar suyu ve kedileri havaya fırlattılar ve "dört" dediğinde ise Salvador Dali havaya sıçrar. Su, kediler ve ünlü ressam Dali hareket halindeyken Halsman deklanşöre basar. Çıkan sonucu beğenmez ve doğru kareyi yakalayabilmek için bu sahneyi 28 kere tekrar ederler. Altı saatin sonunda tamamen bitkin olan Halsman, nihayetinde Dalí Atomicus adını verdiği bir kareyi beğenir (Halsman, 1963, s. 55) (Görsel 8).

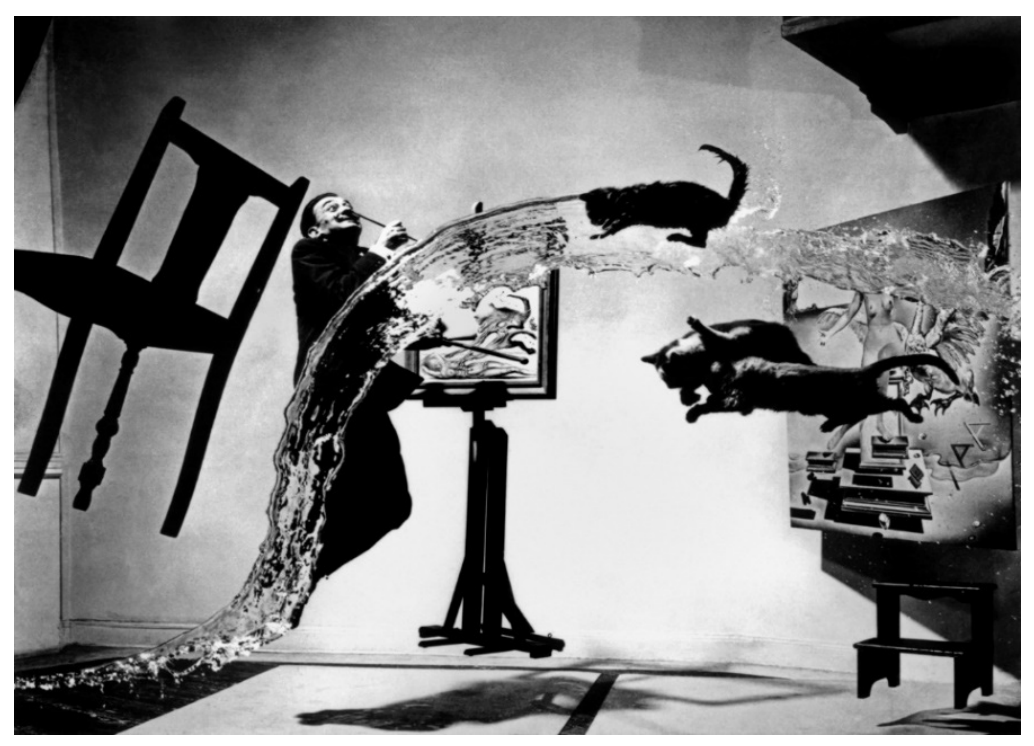

Görsel 8. Philippe Halsman, Dali Atomicus, 1948.

Fotoğraf, gerçeküstü bir içeriğe sahiptir. Çekim aşaması kendisinin de anlatıldığı gibi canlı çekimle eşi ve asistanlarının kadraj dışından yardımı ile üretilmiştir. Hatta kitabında "Ben ve asistanlarım ıslanmış, kirlenmiş ve neredeyse tamamen tükenmiştik. Sadece kediler hâlâ yeni gibi görünüyordu" diye yazar (Halsman, 1963, s. 55).

Fakat yerdeki tablonun gölgesinin boş bir çerçeve olduğunu fark eden bazı fotoğraf eleştirmenleri sonradan tablonun fotoğrafçı tarafından resim ile doldurulduğunu düşünmüşlerdir (Gurney, 2017).

Halsman, sıra dışı fotoğraflar üretmek için üç kurala uyulması gerektiğini savunmaktadır. "Dali Atomicus" isimli çalışmasında bu kuralları sırasıyla şu şekilde yerine getirmiş olur (Luhring, 2002):

1. Sıra dışı teknik uygulama / Cisimlerin havada asılı gibi görünmesini sağlayarak sıra dışı bir teknik kullanır. 
2. Sıra dışı özellik ekleme / Kedileri havaya fırlatarak ve ıslatarak sıra dışı bir özellik ekler.

3. Bir özelliği dışarıda bırakma / Yerçekimini ortadan kaldırarak kompozisyon kurallarından birini dışarıda bırakır.

Fotoğraf, LIFE Dergisi'nde iki sayfa şeklinde yayınlanır ve TIME Dergisi'nin en etkili fotoğraflar listesine girer (Time 100 Photos,

Fotoğrafın 1969-1970 yıllarında yapılmış baskısı, Minneapolis Institute of Arts koleksiyonunda yer almaktadır. Bu baskının arkasında kurşun kalemle "DALI ATOMICUS", 1948 / print C.1969-1970 ve Philippe Halsman ifadesi yazmakta ve yanı sıra C/COPYRIGHT / BY PHILIPPE HALSMAN mührü bulunmaktadır (Altun, 2015).

Özellikle sürrealist bir fotoğrafçı olmamasına rağmen, "hareket"e katkıları zamanın en ünlü sürrealist fotoğraflarını üretmesine neden olmuştur. Nitekim Halsman, sürrealizm akımının en bilinen ressamlarından biri olan Salvador Dali ile çalışmıştır (Ross, 2020).

"Dali Atomicus" adlı çalışma Philippe Halsman'a portre çekimleri hakkında başka bir ilhama neden olur. Audrey Hepburn, Marilyn Monroe, Sophia Loren, Brigitte Bardoł ve daha pek çok ünlünün havada asılı durduğu fotoğraflarını çekmeye başlar. Fotoğraf tarihinde önemli yeri olan bu denemeler katılımcıların (ünlülerin) zıplamasını sağlayarak mümkün olmuştur.

\section{Jumpology (Zıplama Bilimi) ile Çekilen Portre Fotoğrafları ve Yeni Görme Biçimi}

"Hareketin dondurulması" fotoğraf tarihi boyunca spordan savaşa, modadan geziye, haberden sanata akla gelebilecek bütün fotoğraf türlerinde kullanılmıştır. Bu makale, ünlü portre fotoğrafı sanatçısı olan Halsman'ın dönemin yıldız, siyasetçi, yazar, devlet adamı, gazeteci ve sanatçılarını bilerek ve isteyerek havada asılı durdukları anı gösteren ve değişik bir görme biçimi yarattığı teknikle ilgilidir. Bunun için Halsman kamuya mal olmuş ünlüleri zıplamaya ikna etmeyi başarmıştır. Ki "ikna" yeteneği, bir portre fotoğrafçısı için en önemli yeteneklerden birisidir.

Şeylerin havada asılı kalma çalışmalarına 1948'de başlayan Halsman bu tekniği portre çekimlerinde de sürdürmüş ve portre fotoğrafçılığına yeni bir bakış getirmiştir.

Halsman, ünlüleri zıplatarak çektiği fotoğraflar hakkında 1959 yılında Philippe 


\section{arts}

Halsman's Jump Book isimli bir kitap yazar. Kitabında "jumpology" hakkında şu bilgileri vermektedir: Ünlüleri bu yöntemle fotoğraflaması altı yıl sürmüş ve toplamda 176 ünlü simanın fotoğrafını zıplatarak çekmiştir. Halsman, bu fotoğraflama tekniğini "'Jumpology' adını verdiğim yeni bir bilim kurdum" şeklinde açıklamaktadır. Çalışmalarında insanların farklı farklı zıpladıklarını fark ederek bu zıplayışları analiz edebilirsek her insanın karakteri hakkında bilgi edinebileceğimizi de iddia etmiştir (Halsman, 1963, s. 76).

Kitap, Halsman'ın kumsalda kendisinin zıpladığı bir kare fotoğraf ile sona ererken okura "Nasıl zıplarsın?" diye de sorar.

Tıpkı Freud'un rüyaları yorumlaması gibi Halsman da bunun psikolojik bir araç olduğunu ve zıplama tarzları ile insanların karakterleri hakkında bilgi edinebileceğimizi söylemektedir.

Philippe Halman's Jump Book isimli kitabında "En derin dürtülerimizden biri, diğer kişinin neye benzediğini bulmaktır" diye yazar (aktaran Edward, 2006).

Zıplatarak fotoğraf çekme yöntemine nasıl başladığını Halsman on the Creation of Photographic Ideas adlı kitabında ise şöyle açıklar: Bir gün NBC televizyonunda çalışan komedyenlerin bir dizi fotoğraflarını çekmek üzere iş alır. Reklam ve tanıtım amaçı bu komedyenlerin bir oturumda yüzlerce kare fotoğrafını çeker. Değişik ve etkili kareler elde edebilmek için onlardan dans etmelerini, hikayeler anlatmalarını, surat ifadelerini değiştirmelerini ve bir de zıplamalarını ister. Bu fotoğrafların düzeniyle uğraştığı bir başka gün, birdenbire, her komedyenin farklı zıpladığını ve kendi karakterlerinden çıktığını fark eder ve şöyle örnekler: "Jimmy Durante, koca burunlu bir kuş gibi kollarını çırpıyor; Biraz kilolu olan Jack Carson genç ve narin bir eda ile zıplıyor, Dawe Garroway, her zaman yaptığı gibi sıçrarken elini açıp barış işareti yapıyor, Milton Berle ise gerçekte zeki bir adam olmasına rağmen aptal gibi görünmeye çalışıordu" (Halsman, 1963, s. 76).

Halsman bu çalışmadan yola çıkarak tanıdığı diğer ünlülerin nasıl zıplayacaklarını, karakterlerini nasıl ortaya koyacaklarını merak eder. Bu merakla, ünlüleri zıplatıp fotoğraflarını çekmeye başlar.

Komedyenlerden sonra jumpology deneyimine 1952 yılında başladığını belirtir. Ford otomobil şirketinin 50. yıldönümünü kutlama nedeniyle Ford ailesini fotoğraflamak üzere görevlendirilir. İlk önce Bayan Edsel Ford'a kamera karşısında zıplayıp zıplayamayacağını sorar. O da "Topuklu ayakkabılarımla mı?" diye sorarak kabul eder. Ardından gelini ve diğerleri zıpalar. Sonraki altı yıl boyunca Halsman, 
katılımcılardan (ünlülerden) zıplamalarını ister ve projesini tamamlar. Zıplayan ünlüler arasında Windsor Dükü ve Düşesi Richard Nixon, Yargıç Learned Hand (ki o sırada 80'li yaşların ortalarında) gibi devlet adamları da yer almaktadır (Edward, 2006).

Portre, fotoğrafçılı̆ı zor bir alandır. Genellikle insan yüzünden standart duygu ve mimikler beklenir. Verilen pozlar adeta bir maske gibidir. Halsman çalışmalarında fotoğrafladığı ünlülerin maskelerini çıkartıp gerçek benliklerini ortaya koymalarını istemiştir. Böylece fotoğraf sanatına farklı bir görme biçimi kazandırmıştır.

Ekipmanı bir Rolleiflex kamera ve bir elektronik flaşla sınırlıydı ve belirttiği gibi, tek kısıtlama tavanın yüksekliğiydi (Bunyan, 2014). Zıplamalar ünlülerin kabul ettiği her yerde gerçekleşmiştir: Stüdyonun içinde veya dışında, katıımcının (ünlünün) evinde veya işyerinde (Edward, 2006).

Pek çok portre fotoğrafçısı modellerinin iç dünyalarını yüzlerinden okunabileceğini düşünür. Oysa Halsman bu düşüncenin tam tersine; "Birinin yüzüne baktığımızda onun ne düşündüğünü ya da hissettiğini bilemeyiz. Nasıl biri olduğunu bile bilemeyiz. Herkes adeta bir zırh kuşanır ve bir maskenin arkasına saklanır" der (Abel-Hirsch, 2017).

Portre fotoğrafının birinci amacı, kaydedilen görüntünün, fotoğrafı çekilen kişiyi yeterli derecede yansıtmasıdır. Portrenin kişiye açık bir şekilde benzemesinin yanında, kişiliğini yansıtması, karakterini dışa vurması, aynı zamanda estetize edilmiş olması gerekmektedir. Bütün bu özellikleri portre fotoğrafına yansıtırken de kullanılacak en etkili elemanlar vücut, el, kol, ayaklar ve yüz ifadeleridir (Çolak, 2011 , s. 6).

Bu nokłada "yüz" hakkında biraz derinleşmek gerekebilir: Yüz, İbranice' deki karşılığı çoğul anlamda kullanılan "panim"dir ve "bir şeye doğru dönmek" anlamındadır. Fransızca "Visage" (görmek) anlamındadır. Yunanca'da "yüz", "çehre" olarak "başkasının bakışına sunulan şey" anlamındadır. Daha sonra bu sözcük "maske" anlamında kullanılır; özellikle tiyatroda kişilik tanımlamada, oynanan rol ve bu rolü oynayan oyuncuyu karşılar. Bu sözcük daha sonra da "maskenin ardından konuşan kişi" anlamı edinir. Kavram, bu anlamsal evriminde "bizim gözlerimizle gördüğümüz hiçbir zaman kişi değil, ama her zaman, herkesin az ya da çok bilinçli olarak oluşturduğu bir maske, çoğu kez gizemli kalan bir "yüz"dür" ifadesini karşılayacaktır (Paglia, 2014, s. 9).

Ne çok insan yüzü varmış da hiç farkına varmamışım. Bir sürü insan var fakał yüz daha fazla, çünkü her insanın yüzü birkaç tane. Aynı yüzü yıllar yılı taşıyanlar: tabii eskir bu yüz, kirlenir, kıvrımlarından aşınır, yolculukta giyilen 


\section{arts}

eldivenler gibi bollaşır... (Batur, 2004, s. 313).

Yüzler aynı basit taslak üstünden yapılmış sonsuz sayıda çeşitlemedir. Onlara biçim veren malzemenin sayısı bu kadar kısıtlıyken (ağız, burun, gözler, alın vb.) biçim ve ifade çeşitlerinin bu denli zengin olması şaşırłıcıdır. Yüz sahnesinin darlığı birleşim çokluğuna kesinlikle engel olmaz...Yüzün biçimini oluşturan öğelerden birindeki küçücük bir değişiklik onun düzenini ve anlamını bozar (Le Breton, 2018, s. 12).

Barthes' e göre portre fotoğrafı kapalı bir kuvvetler alanıdır. Burada dört görüntü repartuvarının kesiştiğinden, birbirine karşı koyduğundan bahseder. "Bunlar: Mercek önündeki ben, aynı anda: Olduğumu sandığım, başkalarının olduğumu sanmalarını istediğim, fotoğrafçının olduğumu sandığı ve fotoğrafçının sanatını göstermek için kullandığıyımdır" der ve portre fotoğrafı çektirdiğinde adeta ölümün mikro düzeyde bir çeşidini yaşadığını söyler (Barthes, 2000, s. 27-28).

Bu yazılanlardan insanların birden çok yüzü olduğunu anlamaktayız. Gerçek yüzümüz çok çeşitli şekillerde kendini maskelemektedir. Yüzdeki asıl gerçekliğin ne olduğunu anlamaya çalışan sanatçılar, kendilerine göre birtakım yanıtlar arama çabasına girmişlerdir. Halsman modelin hem dışını hem de içini en iyi şekilde ortaya koyacağını düşündüğü bir çekim tekniği geliştirmiştir.

Bu çekim tekniği ve portrelerin karakterlerini yansıtmasıyla ilgili olarak kitabında "Insan zıpladığında yüzündeki maske düşer ve gerçek benlik görünür hale gelir" şeklinde çarpıcı bir açıklamada bulunur (Halsman, 1963, s. 76-77). Halsman'a göre insan, zıplarken sahte gülüş ve surat ifadesi veremez. Artık, ne ise odur.

Halsman kendi web sitesinde insanları neden zıplattığını ise şu şekilde açıklamıştır (Philippe Halsman Archive, 2015):

1950'lerin başlarından itibaren fotoğrafladığım ünlü veya önemli herkesten benim için zıplamasını istedim. Gerçek bir merakla bu işe motive oldum.

Sonuçta, yaşam bize yüz ifadelerimizi kontrol etmeyi ve gizlemeyi öğretti, ama

bize ałlamalarımızı, zıplamalarımızı kontrol etmeyi öğretmedi. Ünlü insanların

hırslarını, eksikliklerini, özgüven ya da güvensizliklerini ve diğer birçok özelliğini

bir sıçrama ile ortaya çıkarmak istedim.

Halsman'a göre, fotoğrafçıya poz vermek yerine zıplayan kişiler, fotoğrafın çekildiği anda duygusal açıdan dengesiz yakalanıyorlardı ve bu fotoğraflarla zıplayan kişilerin kişiliklerinin çeşitli özellikleri belirlenebilirdi (Altun, 2015).

Zıplayan kişinin vücudundaki her uzvunun (kollarının, bacaklarının, vücudun pozisyonunun, yüz ifadesinin) belirli karakter özelliklerini ortaya çıkardığını savunmaktadır. Örneğin Marilyn Monroe, Grace Kelly ve Brigitte Bardot'un zıplarken dizlerini kırmaları onların çocuksu yanlarını ortaya çıkarmaktadır. Oysa bu kadınlar 
cinselliği temsil etmektedirler. Demek ki bu temsil aslında kendi arzularının bir yansıması değildir (Abel-Hirsch, 2017).

Çalışmasını iki külliyat şeklinde bir ayrımla gerçekleştirmiştir. Birincisi farklı alanlardan (politik, endüstriyel, bilimsel, teolojik, edebi, vb.) etkili şahsiyetlerin fotoğraflarını çekmiştir. Böylece resmî kimlikleriyle tanınan bu kişilerin resmî imajıyla çelişen beklenmedik portreleri ortaya çıkmıştır. İkincisi ise oyuncular, şarkıcılar, dansçılar gibi gösteri dünyasının sanatçılarıdır (Bunyan, 2014).

Aşağıda Halsman'ın iki kategoride gerçekleştirdiği çekimlerden bazıları yer almaktadır. İlk altı fotoğraf gösteri dünyasının (Görsel 9-14) diğer altı fotoğraf ise kamuya mal olmuş devlet adamları, siyasetçi, sanatçı ve aydınlara (Görsel 15-20) aittir. Fotoğrafların çoğu Halsman'ın resmî web sitesinde bulunmaktadır.
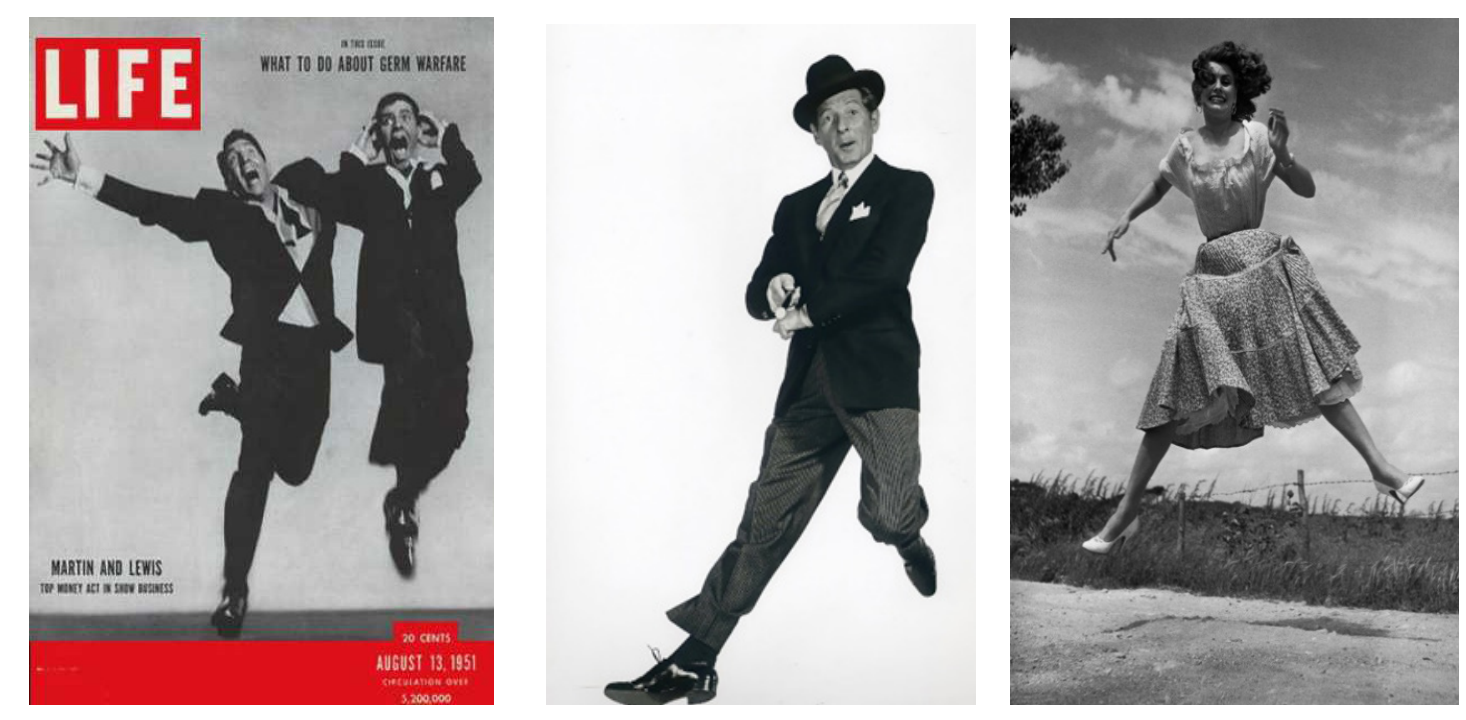

Görsel 9. Philippe Halsman, Dean Martin ve Jerry Lewis, 1951.

Görsel 10. Philippe Halsman, Danny Kaye, 1954.

Görsel 11. Philippe Halsman, Sophia Loren, 1955. 

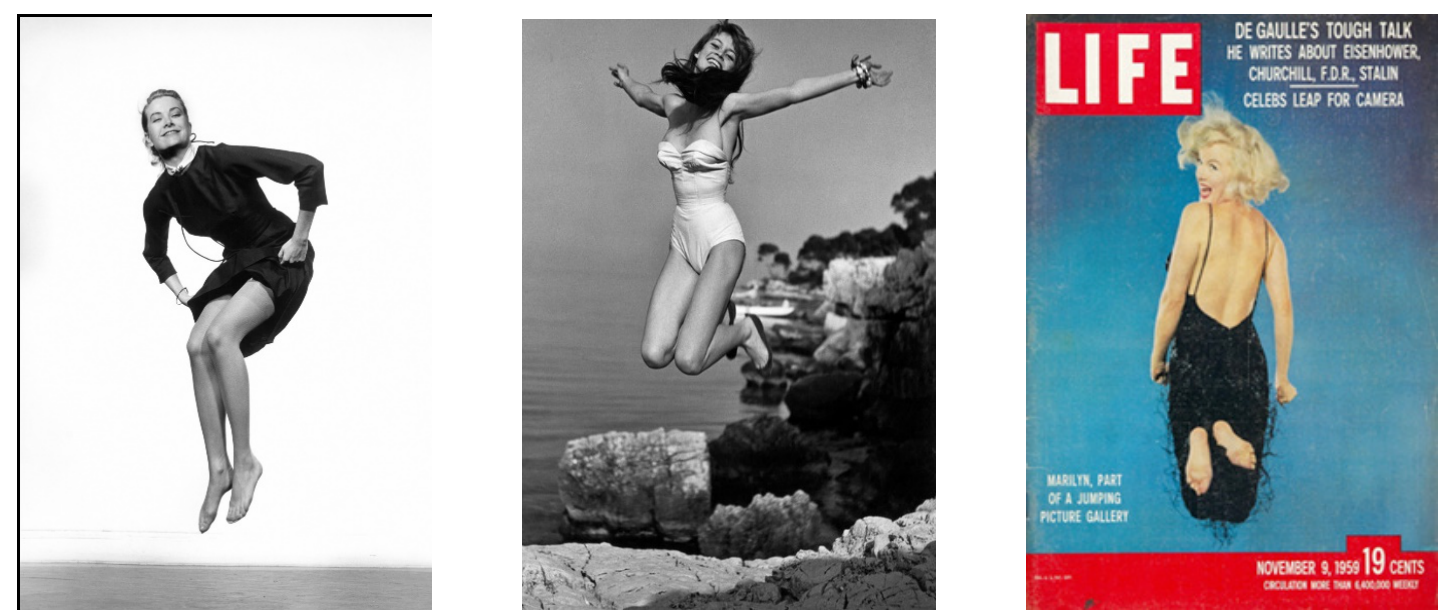

Görsel 12. Philippe Halsman, Grace Kelly. 1955.

Görsel 13. Philippe Halsman, Brigitte Bardot, 1955.

Görsel 14. Philippe Halsman, Marilyn Monroe, 1959.
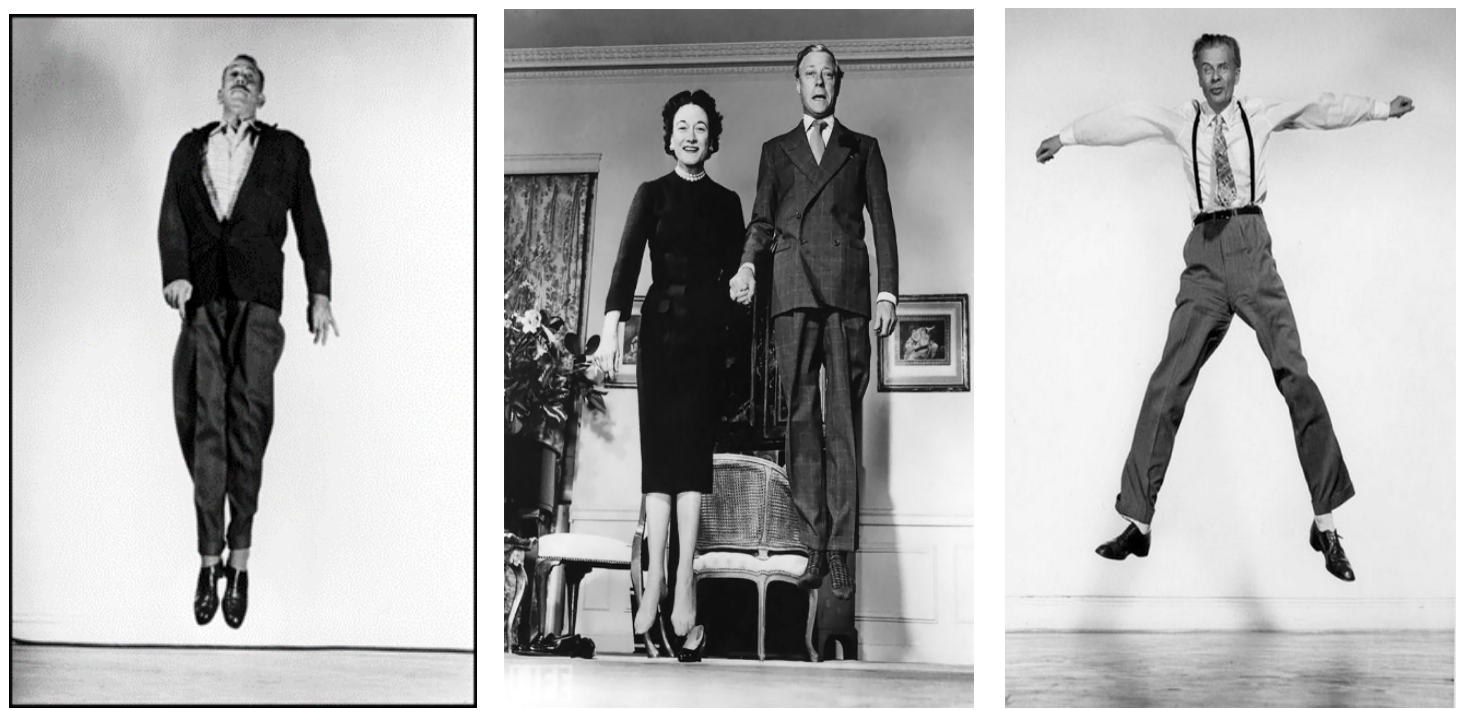

Görsel 15. Philippe Halsman, John Steinbeck 1953

Görsel 16. Philippe Halsman, Windsor Dükü ve Düşesi, 1958.

Görsel 17. Philippe Halsman, Aldous Huxley, 1958. 

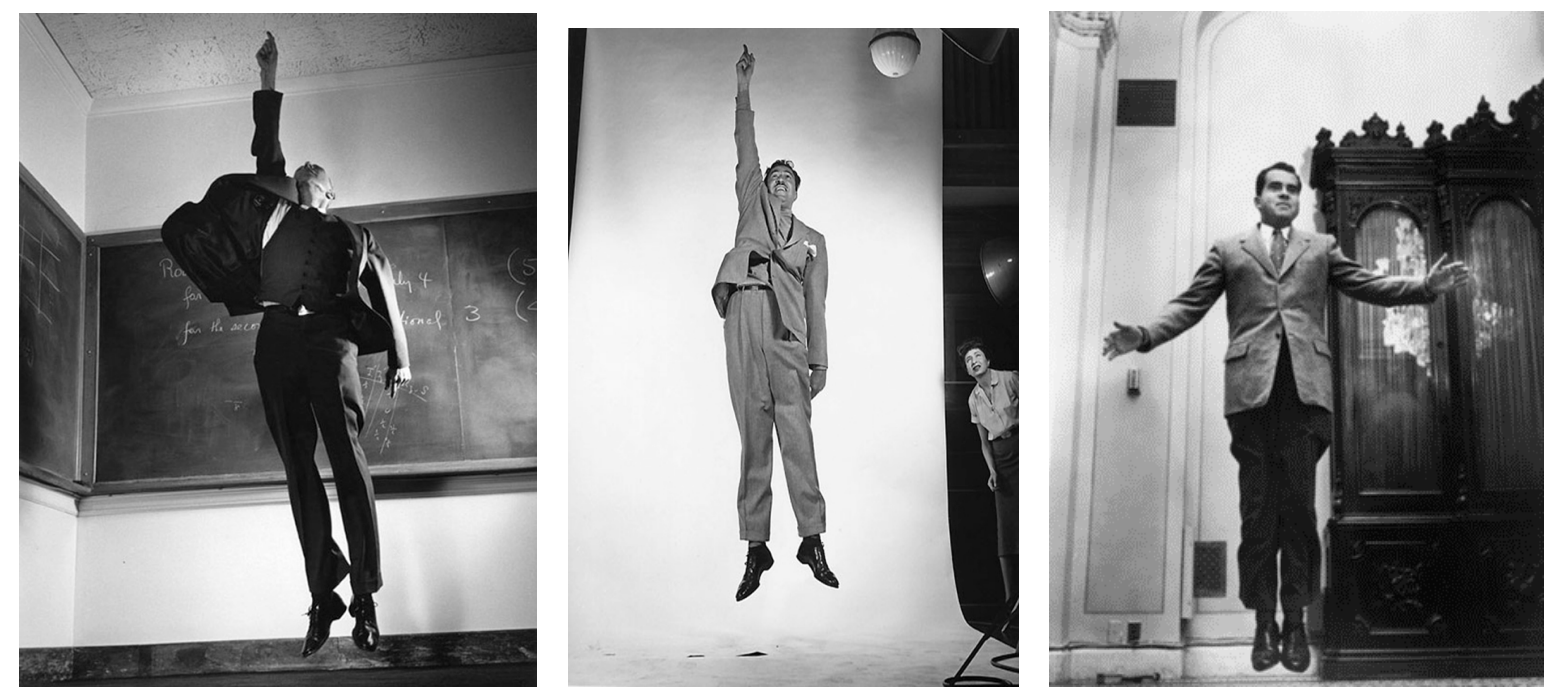

Görsel 18. Philippe Halsman, Prof. J.Robert Oppenheimer, 1958.

Görsel 19. Philippe Halsman, Adam Clayłon Powell, 1959.

Görsel 20. Philippe Halsman, Richard Nixon, 1959.

Halsman, zıplayan bu insanları ayrıca olabildiğince yukarı zıplamaya çalışanlar ve bunu umursamayanlar olarak da ikiye ayırmaktadır. Zıplamak için çok çabalayanlar başkalarını etkilemeye çalışan hırslı kişilerdir. En yükseğe zıplayabilmeyi umursamayanları ise hırsları olmayanlar veya atlamayı ciddiye almayanlar şeklinde yorumlamaktadır (Abel-Hirsch, 2017).

Ünlüler fotoğrafçılara poz verme eğilimindedirler, ancak kendilerinden zıplamaları istendiğinde sert, eğlenceli veya zihinsel olarak dengesiz olup olmadıkları ortaya çıkacaktır. Onlar için büyük risk olmasına rağmen Halsman'ın bu kadar kendine güvenen ünlüyü zıplama konusunda nasıl ikna ettiği bilinmemektedir. Üstelik birçoğu zıplamayı kabul ettiği gibi yayımlanmasına da izin vermiştir (aktaran Luhring, 2002).

Halsman, çektiği bütün ünlü kişilerde hem ünlerini hem de kendilerini göstermeyi başarmaktadır. Işık-obje arasındaki ikilemi Halsman sık sık poz içinde hareketi üreterek aşmaktadır (Tulgar, 2007, s. 38).

Ünlüleri zıplatmayı ikna gücü sayesinde başarmıştır. Çünkü siyasetçiler, kraliyet mensupları yani zıplayacağı tahmin edilemeyecek simalar Halsman için zıplamışlardır.

1958' de Popular Photography tarafından yapılan bir ankette Halsman, Irving Penn, Richard Avedon, Ansel Adams, Henri Cartier-Bresson, Alfred Eisenstaedt, Ernst Haas, Yousuf Karsh, Gjon Mili ve Eugene Smith ile birlikte "Dünyanın En Büyük 


\section{arts}

On Fotoğrafçısı" arasına girmiştir (Panzer, ). 1975 yılında ise Amerikan Dergi Fotoğrafçıları Derneği'nden "Fotoğrafta Yaşam Boyu Başarı" Ödülü almıştır. Dünya çapında büyük sergiler açmışıır.

Eserleri bugün New York Modern Sanat Müzesi, New York Uluslararası Fotoğraf Merkezi, Los Angeles Paul Getty Müzesi, Indianapolis Sanat Müzesi, Washington Ulusal Portre Galerisi, Washington Kongre Kütüphanesi'nin daimî koleksiyonlarında yer almaktadır (Philippe Halsman Archive, 2015).

\section{SONUÇ}

Çalışmamızda ilk önce en az zıplama fotoğrafları kadar değerli ve önemli olan Dali Atomicus adlı eserin çekim öncesi ve sonrası hakkında kısa bir açıklama yapılmıştır. Sebebi Halsman'ın havada asılı kalma kavramını ilk uyguladığı proje olmasıdır. 1941 'de tanıştığı ve çok yakın olduğu sürekli fikir alışverişinde bulunduğu Salvador Dali ile tasarladıkları bu fotoğraf, birkaç yıl sonra uygulamaya başlayacağı ve altı yıl sürdüreceği zıplama bilimine (jumpology) kaynaklık etmiştir. Fotoğraf gerçeküstü bir niteliğe sahiptir.

Halsman, 1961 yılında yazdığı Halsman on the Creation of Photographic Ideas kitabında sıra dışı fotoğraflar üretmek için üç kurala uyulması gerektiğinden söz eder. Bunlar sıra dışı bir teknik uygulama, sıra dışı bir özellik ekleme ve bir özelliği dışarıda bırakma şeklindedir. Yukarıda da söz edildiği gibi cisimleri havada asılıymış gibi tutarak, kedileri havaya fırlatıp ıslatarak ve yerçekimini ortadan kaldırarak bunu başarır. Sonradan zıplama fotoğraflarında da görüleceği gibi sıra dışı portre fotoğrafları üretme açısından bu maddelerin en az ikisi (havada asılı kalma ve yerçekimini göz ardı etme) aynı şekilde geçerlidir. Sıra dışı özellik ekleme her portrede yoktur, ancak ünlülerin zıplama anındaki sıra dışı davranışları ve yüz ifadeleri bu şekilde değerlendirilebilir. O yüz, aslında önceden hiç böyle görülmemiştir.

1940'lardan 1970'lere kadar Philippe Halsman'ın çektiği portreler LIFE, TIME, Look, Esquire, Saturday Evening Post, Paris Match gibi tirajı yüksek, önemli fotoğraflı dergilerin kapaklarında ve sayfalarında yer almıştır. Gösteri dünyasının yıldızlarından siyasetçilere, ressamlardan futbolculara, yazarlardan bilim insanlarına dek kendinden söz ettiren, kamuya mal olan bu ünlülerin yüzleri Halsman tarafından fotoğraflanmış, okurun beğenisine sunulmuştur.

Kişiliği oluşturan sayısız duygusal ifadelerin taşıyıcısı olarak bir yüze sahip olan 
insan, bu ifadelerin izlerinin açığa çıkmaması için farklı nedenlerden dolayı zaman zaman yüzünü gizleme intiyacı hisseder. Sayısız ifadelerin toplandığı yüz, bu ifadeleri kim bilir kaç kez ödünç alıp vermiştir?... Bütün dünyaya kendini açan yüz, kimi zaman görünür gerçekliğin ötesinde, görünmeyen ya da gösterilmeyen iç gerçekliklerini saklayarak anlaşmazlıklarını ve sessizliklerini yansııı (Edeer, 2016, s.121).

Portre fotoğrafçısı Halsman, fotoğrafını çektiği kişilerin özünü yakalamak için çaba sarf etmiştir. Hep insanların kendi gerçek iç yüzünü merak etmiş, bunu ortaya çıkartmaya çalışmıştır.

Sanatçı, fotoğrafçıların kişileri belli bir pozisyona soktukları ve başlarını belli bir açıya yerleştirdikleri çekimle doğal fotoğrafı yakalayamayacaklarını düşünmektedir. Ona göre ünlüyü kışkırtarak, şakalarla eğlendirerek ya da en yakınının bile kendisine soramayacağı kadar küstah sorular sorarak o kişilerden ilginç ve başarılı portre fotoğrafları elde edilir (Panzer,

1950'lerde Halsman spontane, aniden ortaya çıkan orijinal portre fotoğrafları yaratmanın bir yolunu daha bulmuştur. "Jumpology" adını verdiği değişik bir fotoğraflama tekniği ile yeni bir görme biçimi ortaya çıkarır. İnsanların zıpladığında en doğal ve en yalın halini yakalayabileceğini ve zıplayan insanın gerçek kişiliğinin okunabileceğini işte bu "Jumpology" dediği bilimle açıklamaya çalışır.

Sanatçıya göre bir insan zıpladığında tüm dikkatini zıplamaya verir, kendini unutur ve yüzündeki maske düşer. Yani böylece gerçek kişiliği de ortaya çıkmaktadır. Özellikle ünlülerin verdiği standart duruş ve sahte bakışlarla poz veren yüzlerin bu teknikle birlikte değişebileceğine inanmaktadır. Iş̧te bu zıplama anında fotoğrafçı bir fotoğraf makinesi ile bunu tespit etmelidir.

Freudcu psikanalizin rüyaları yorumladığı gibi Halsman da zıplamaların her birinin bir anlamı ortaya çıkardığını iddia eder. Zıplama anı fotoğrafı incelenecek olursa kişinin vücudundaki her uzvun (kolların, bacakların, vücudun konumunun, yüz ifadesinin) tek tek belirli karakter özelliklerine denk geleceğini düşünür.

Halsman'ın portre sanatındaki başarısı şüphesiz ki ünlülerle kurduğu iyi diyaloğa, etkili iletişime ve ikna yeteneğine bağlıdır. Toplumun tanıdığı ünlü yüzler onun bu çılgın fikrine olumlu yanıt vermişler, acayip görünebilme riskini göze alarak zıplamışlar ve fotoğrafların yayınlanmasını da kabul etmişlerdir. Bu ünlülerin yarısı gösteri dünyasına (sinema, sahne, tiyatro yıldızı, şöhreti) aitken diğer yarısı siyasetçi, devlet adamı, aydın, bilim insanı gibi ciddi kişilikleriyle tanınan insanlardır. Marilyn Monroe, Edward Steichen, Audrey Hepburn, Robert Oppenheimer, John Steinbeck, 


\section{arts}

Weegee, Aldous Huxley, Marc Chagall, Salvador Dali, Brigitte Bardot, Grace Kelly ve Groucho Marx Halsman için zıplayan ünlülerden bazılarıdır.

1959 yılında Damiani Yayınevi tarafından Philippe Halsman's Jump Book adlı kitabı basılmıştır. Kitabın ilk baskısında 176, ikinci(1989) ve üçüncü baskısında (2015) ise 191 ünlü kişiye ait olan zıplama fotoğrafı yer almaktadır. Havada asılı kalan film yıldızlarının, politikacıların, kraliyet ailesinin, sanatçıların ve yazarların bu benzersiz esprili ve enerjik görüntüleri, Halsman'ın fotoğraf mirasının önemli bir parçası olduğu kadar dünya fotoğraf kültürünün de önemli bir parçasını oluşturmaktadır.

Hayata veda eden pek çok ünlü bugün Halsman'ın çektiği portrelerle anılmaktadır.

Bu teknik, geleceğin portre fotoğrafçılarının ve özellikle de ünlülerin portreye bakışını değiştirmiştir. Farklı bir görme biçimi ile portre fotoğrafları çeken Halsman'ın bu çalışmaları diğer fotoğrafçıların özgün fotoğraflar çekmek için çaba sarf etmelerine neden olmuş ve birçok fotoğrafçıya ilham kaynağı olmuştur.

\section{KAYNAKÇA}

Abel-Hirsch, H. (2017, 13 Ağustos). Philippe Halsman: Jump. Magnum Photos. https://www.magnumphotos.com/arts-culture/philippe-halsman-jump-book/. Erişim Tarihi: 5 Mart 2021

Altun, Y. (2015). Bir Fotoğrafın Hikayesi "Dali Atomicus". https://www. fotografine.com.tr/fotograf-yazilar/bir-fotografin-hikayesi-dali-atomicus/. Erişim Tarihi: 1 Mart 2021

Barthes, R. (2000). Camera Lucida (Çev. R. Akçayaka). İstanbul: Altıkırkbeş.

Batur, E. (2004). Başkalaşımlar I-X. İstanbul: Yapı Kredi.

Bunyan, M. (2014, 14 Mayıs). exhibition: 'philippe halsman, astonish me!' at the musée de l'elysée. Art Blart. https://artblart.com/2014/05/04/exhibition-philippehalsman-astonish-me-at-the-musee-de-lelysee-lausanne/. Erişim Tarihi: 4 Marł 2021

Çolak, O. (2001). Portre Fotoğrafı Nasıl Çekilir? İstanbul: Doğan Burda.

Dali, S. (1949). Leda Atomica [Resim]. http://www.sanatteorisi.com/ sanatteorisi.asp? sayfa=Galeri\&icerik=Goster\&id=2768. Erişim Tarihi: 7 Mart 2021

Edeer, Ş. (2016). Yüzün Bakışı. Eskişehir: Nisan. 
Edgerton, H. E. (1936). Milk Drop [Fotoğraf]. https://www.researchgate.net/ publication/257403646_High-speed_imaging_in_fluids\#fullTextFileContent. Erişim Tarihi: 3 Mart 2021

Edward, O. (2006). When He Said "Jump..." Philippe Halsman defied gravitas. Smithsonian Magazine. https://www.smithsonianmag.com/arts-culture/when-hesaid-jump-130897523/. Erişim Tarihi: 5 Mart 2021

Golden, F. (1999). Albert Einstein - Person of the Century. http://content.time. com/time/magazine/article/0,9171,993017-1,00.html. Erişim Tarihi: 7 Mart 2021

Gurney, J. (2017). Dali and Halsman Capture a Moment. http://gurneyjourney. blogspot.com/2017/11/dali-and-halsman-capture-moment.html. Erişim Tarihi: 3 Mart 2021

Halsman, P. (1941). Connie Ford [Fotoğraf]. https://tr.pinterest.com/ pin/218706125646401170/. Erişim Tarihi: 7 Mart 2021

Halsman, P. (1947). Albert Einstein - Person of the Century (1999) [Fotoğraf]. http://content.time.com/time/covers/0, 16641,19991231,00.html. Erişim Tarihi: 7 Mart 2021

Halsman, P. (1948). Dali Atomicus [Fotoğraf]. http://100photos.time.com/ photos/philippe-halsman-dali-atomicus._Erişim Tarihi: 8 Marł 2021

Halsman, P. (1951). Dean Martin ve Jerry Lewis [Fotoğraf]. http:// philippehalsman.com/?publication=magazine-covers. Erişim Tarihi: 8 Mart 2021

Halsman, P. (1952). Marilyn Monroe [Fotoğraf]. http://philippehalsman. com/?.publication=magazine-covers. Erişim Tarihi: 7 Mart 2021

Halsman, P. (1953). John Steinbeck [Fotoğraf]. https://www.magnumphotos. com/arts-culture/philippe-halsman-jump-book/. Erişim Tarihi: 8 Mart 2021

Halsman, P. (1954). Salvador Dali [Fotoğraf]. http://philippehalsman. com/?image=iconic-images. Erişim Tarihi: 7 Marł 2021

Halsman, P. (1954). Danny Kaye [Fotoğraf]. http://philippehalsman. com/?.image=jumps._Erişim Tarihi: 7 Mart 2021

Halsman, P. (1955). Sophia Loren [Fotoğraf]. https://www.vintag.es/2011/10/ jumpology-by-philippe-halsman.html. Erişim Tarihi: 8 Mart 2021 


\section{arts}

Halsman, P. (1955). Grace Kelly [Fotoğraf]._http://philippehalsman. com/?image=jumps._Erişim Tarihi: 7 Marł 2021

Halsman, P. (1955). Brigitte Bardot [Fotoğraf]._http://philippehalsman. com/?:image=jumps._Erişim Tarihi: 7 Marł 2021

Halsman, P. (1958). Windsor Dükü ve Düşesi [Fotoğraf]. https://tr.pinterest. com/pin/539939442825680337/. Erişim Tarihi: 7 Mart 2021

Halsman, P. (1958). Aldous Huxley [Fotoğraf]. https://www.vintag.es/201 1/10/ jumpology-by-philippe-halsman.html. Erişim Tarihi: 8 Mart 2021

Halsman, P. (1958). Prof. J. Robert Oppenheimer [Fotoğraf]. https://tr.pinterest. com/pin/539939442825680337/. Erişim Tarihi: 7 Mart 2021

Halsman, P. (1959). Marilyn Monroe [Fotoğraf]. http://philippehalsman. com/?publication=magazine-covers. Erişim Tarihi: 7 Mart 2021

Halsman, P. (1959). Richard Nixon [Fotoğraf]. http://philippehalsman. com/?image=jumps._Erişim Tarihi: 7 Marł 2021

Halsman, P. (1959). Adam Clayton Powell [Fotoğraf]. https://www.vintag. es/201 1/10/jumpology-by-philippe-halsman.html. Erişim Tarihi: 7 Mart 2021

Halsman, P. (1962). Alfred Hitchcock [Fotoğraf]. http://philippehalsman. com/?image=iconic-images._Erişim Tarihi: 7 Mart 2021

Halsman, P. (1963). Halsman on the Creation of Photographic Ideas (Third Printing), New York: A. S. Barnes.

Le Breton, D. (2018). Yüz Üzerine Antropolojik Bir Deneme (Çev. O. Türkay). İstanbul: Boğaziçi Üniversitesi.

Luhring, B. (2002). Philippe Halsman: Dali Atomicus. https://web.archive.org/ web/20090903050554/http://www.luhring-design.com/information/essays/daliatomicus/philippe-halsman.html. Erişim Tarihi: 4 Mart 2021

Neret, G. (1997). Öncü Ressamlar Dali (Çev. A. Antmen). İstanbul: ABC.

Paglia, C. (2014). Cinsel Kimlikler (Çev. F. Demirci ve A. Hazaryan). Ankara: Epos.

Panzer, M. (__ (_ Philippe Halsman: A Retrospective. https://npg.si.edu/exh/ halsman/intro.htm. Erişim Tarihi: 7 Mart 2021 
Philippe Halsman Archive (2015). Halsman. http://philippehalsman.com/ halsman/. Erişim Tarihi: 5 Mart 2021

Ross, J. (2020). Philippe Halsman: Early Contributorto the Surrealist Photography Movement. The Collector. https://www.thecollector.com/philippe-halsman/. Erişim Tarihi: 4 Mart 2021

Sanata Başla (2014, Kasım). Atomsal Leda "Leda Atomica"- Dali. https:// www.sanatabasla.com/2014/11/atomsal-leda-leda-atomica-dali/ Erişim Tarihi: 4 Mart 2021

Time 100 Photos. (__). Dali Atomicus-Philippe Halsman. http://100photos. time.com/photos/philippe-halsman-dali-atomicus. Erişim Tarihi: 3 Mart 2021

Tulgar, A. (2007). Philippe Halsman Yıldızın Işık Meselesi. Fotoğrafevi İz Dergisi, No: $9,2007 / 3,38-51$.

Versluis, M. (2013). High-speed imaging in fluids. Experiments in Fluids, 54(2). https://www.researchgate.net/publication/257403646_High-speed_imaging_in_ fluids\#fullTextFileContent. Erişim Tarihi: 3 Mart 2021 